Aspirasi: Jurnal Masalah-Masalah Sosial | Volume 10, No. 1 Juni 2019

ISSN: 2086-6305 (print) ISSN: 2614-5863 (electronic)

DOI: https://doi.org/10.22212/aspirasi.v7il.1084

link online: http://jurnal.dpr.go.id/index.php/aspirasi/index

\title{
IMPLEMENTASI KEBIJAKAN PROGRAM PEMBANGUNAN PARTISIPATIF BERBASIS KOMUNITAS (P3BK) DI KECAMATAN PONDOK MELATI KOTA BEKASI
} \author{
Pondok Melati Sub-district, Bekasi City \\ *Indrawaty Gita , **Mohammad Mulyadi \\ indrawatigita@gmail.com \\ *Pemerintah Kota Bekasi \\ **Pusat Penelitian Badan Keahlian DPR RI \\ Jl. Gatot Subroto Senayan Jakarta
}

Implementation of Community Based Participatory Development Program Policy in

Naskah Diterima: 9 Maret 2019| Naskah direvisi: 10 Juni 2019| Naskah diterbitkan: 29 Juni 2019

\begin{abstract}
The Community-Based Participatory Development Program (P3BK) is the Bekasi City Government Program for the implementation of development through community participation and self-help. This paper wants to describe the implementation of the P3BK policy in Pondok Melati District, Bekasi City. This research is qualitative in nature where data is collected through interviews with self-managed P3BK pelaksanas, then the data is analyzed by Miles and Huberman Models. Overall the program went well, which was based on several factors, namely: (1) communication, which included the distribution of effective communication, sufficient clarity on the P3BK policy by the pelaksanas of the activities, as well as consistency in providing good direction; (2) resources, including competent and capable enough human resources; (3) the disposition/attitude of P3BK pelaksanas: sufficient capacity and capability and high dedication of P3BK pelaksanas; (4) organizational structure/bureaucracy, including the availability of Standard Operating Procedure (SOP) for P3BK implementation and each program pelaksana has understood and implemented the $S O P$, as well as effective bureaucratic fragmentation.
\end{abstract}

Keywords: Development. Participation, Policy, Community

\begin{abstract}
Abstrak: Program Pembangunan Partisipatif Berbasis Komunitas (P3BK) merupakan Program Pemerintah Kota Bekasi untuk pelaksanaan pembangunan lewat partisipasi dan swadaya masyarakat. Tulisan ini ingin mendeskripsikan implementasi kebijakan P3BK di Kecamatan Pondok Melati Kota Bekasi. Penelitian ini bersifat kualitatif di mana data dikumpulkan melalui wawancara pada pelaksana swakelola P3BK, kemudian data dianalisis dengan Model Miles dan Huberman. Secara keseluruhan program berjalan baik, yang didorong beberapa faktor yaitu: (1) komunikasi, yang meliputi penyaluran komunikasi yang cukup efektif, kejelasan yang cukup baik atas kebijakan P3BK oleh para pelaksana kegiatan, serta konsistensi dalam memberikan arahan yang cukup baik; (2) sumber daya, yang meliputi SDM pelaksana program yang dinilai cukup kompeten dan kapabel; (3) disposisi/sikap pelaksana P3BK, yang meliputi kapasitas dan kapabilitas pelaksana P3BK yang cukup memadai, dedikasi yang tinggi. (4) struktur organisasi/ birokrasi, yang meliputi telah tersedianya Standar Operasional Prosedur (SOP) pelaksanaan P3BK dan masing-masing pelaksana program telah memahami dan melaksanakan SOP tersebut, serta fragmentasi birokrasi yang telah berjalan efektif.
\end{abstract}

Kata kunci: Pembangunan, Partisipasi, Kebijakan, Komunitas. 


\section{Pendahuluan}

Pembangunan adalah upaya manusia dalam mengubah sesuatu agar menjadi lebih baik secara kuantitas maupun kualitas. Pembangunan identik dengan perubahan atau pertambahan fisik, seperti bangunan jalan, jembatan gedung dan lain sebagainya. agar pembangunan dapat berjalan dengan baik maka dibutuhkan kerja sama antara pemerintah dan masyarakat, karena masyarakatlah yang akan merasakan manfaat dari pembangunan. Oleh karena itu, pembangunan harus berorientasi pada pada peningkatan kualitas hidup manusia, bukan pada pertumbuhan ekonomi melalui pasar maupun memperkuat negara. Hal ini sesuai dengan pendapat Mulyadi (2012:11) bahwa pemerintah perlu memikirkan strategi yang 'ampuh' agar segala upaya yang diarahkan untuk mencapai sasaran pembangunan milenium dapat terwujud. Salah satu cara yang perlu mendapatkan perhatian serius dari pemerintah adalah peningkatan kualitas sumber daya manusia. Karena dengan begitu, diharapkan sumber daya manusia yang ada mampu bersinergi dalam kegiatan pembangunan.

Salah satu kebijakan pembangunan nasional yang dirumuskan dalam program pemberdayaan masyarakat adalah Program Pengembangan Kelembagaan Keswadayaan yang bertujuan untuk mengembangkan kelembagaan keswadayaan atau volunter berfungsi dalam penggalangan solidaritas sosial dan partisipasi masyarakat luas untuk memecahkan masalah sosial kemasyarakatan dan meningkatkan ketahanan sosial masyarakat (“Ancaman Banjir", 2013).

Kebijakan dan program tersebut diturunkan dan dijabarkan pula melalui kebijakan pembangunan Kota Bekasi yang tertuang dalam dokumen Rencana Pembangunan Jangka Menengah Daerah (RPJMD) Kota Bekasi Tahun 2013-2018. Upaya pencapaian Visi Kota Bekasi yang Maju, Sejahtera dan Ihsan dijabarkan melalui 5 Misi, yaitu: menyelenggarakan tata kelola kepemerintahan yang baik; membangun prasarana dan sarana yang serasi dengan dinamika dan pertumbuhan kota; meningkatkan kehidupan sosial masyarakat melalui layanan pendidikan kesehatan dan layanan sosial lainnya; meningkatkan perekonomian melalui pengembangan usaha mikro, kecil dan menengah, peningkatan investasi, serta penciptaan iklim usaha yang kondusif; mewujudkan kehidupan masyarakat yang aman, tertib, tentram dan damai.

Misi ke-5 sejalan dengan isu strategis yang dihadapi Kota Bekasi, yaitu pemberdayaan masyarakat dan keamanan ketertiban. Hal tersebut selanjutnya menjadi dasar perumusan salah satu arah kebijakan pembangunan Kota Bekasi, yaitu peningkatan kesejahteraan masyarakat melalui pemberdayaan masyarakat. Arah kebijakan tersebut kemudian dijabarkan dalam beberapa program. Adapun program yang menjadi prioritas adalah Peningkatan Partisipasi Masyarakat Dalam Pembangunan.

Program Peningkatan Partisipasi Masyarakat Dalam Pembangunan menjadi prioritas, karena Kota Bekasi sedang menghadapi permasalahan, yakni peningkatan jumlah penduduk secara pesat seiring berkembangnya Bekasi menjadi kota mitra dari ibu kota negara, DKI Jakarta. Dengan jumlah penduduk lebih dari 2,6 juta jiwa, Kota Bekasi yang memiliki luas wilayah $200 \mathrm{~km}^{2}$ terbagi ke dalam 12 kecamatan dan 56 kelurahan, dan komposisi penduduk yang sangat heterogen baik dari segi jenjang pendidikan maupun latar belakang suku dan agama, maka Bekasi merupakan kota yang harus mampu merencanakan pembangunannya dengan baik guna mendukung tujuan pembangunan nasional, yaitu peningkatan kualitas hidup manusia. Salah satunya adalah program pembangunan yang mendorong adanya partisipasi masyarakat secara aktif.

Pembangunan yang menekankan pada transformatif and transactive planning, bottom up, community empowerment and participative kemudian dikenal dengan pemberdayaan masyarakat. Oleh karena itu pembangunan pada dasarnya adalah pemberdayaan yang mengacu pada upaya memandirikan masyarakat. Kota Bekasi telah merencanakan, menetapkan, dan melaksanakan kebijakan pembangunan tersebut melalui Program Pembangunan Partisipatif Berbasis Komunitas (P3BK). P3BK adalah program bantuan kepada masyarakat melalui 
Badan Keswadayaan Masyarakat (BKM) yang bertujuan untuk meningkatkan partisipasi masyarakatdalampenyelenggaraanpembangunan daerah atau secara fungsional terkait dengan dukungan penyelenggaraan pemerintahan daerah dengan pendekatan berbasis komunitas di tingkat Rukun Tetangga (RT)/ Rukun Warga (RW) (Peraturan Walikota Bekasi, 2016). Upaya pendekatan pengelolaan pembangunan daerah yang berbasis pada pemberdayaan masyarakat dan komunitas merupakan pendekatan yang relatif efektif dalam penyelenggaraan programprogram pembangunan yang dilaksanakan di Kota Bekasi.

Berbagai hal yang diidentifikasi sebagai permasalahan, potensi, dan kendala dalam implementasi P3BK di Kota Bekasi serta perbedaan tingkat partisipasi masyarakat dalam pelaksanaan $\mathrm{P} 3 \mathrm{BK}$, menjadi dasar penulis untuk melakukan penelitian guna mempelajari, menganalisis, dan memberikan gambaran implementasi kebijakan Pemerintah Kota Bekasi melalui P3BK dan tingkat partisipasi masyarakat Kota Bekasi dalam pembangunan Kota Bekasi melalui P3BK.

Setelah peneliti melakukan identifikasi serta pembatasan masalah yang akan diteliti, maka dirumuskan permasalahan yang akan diangkat dalam penelitian ini sebagai berikut: Bagaimana implementasi kebijakan P3BK di Kecamatan Pondok Melati Kota Bekasi? Adapun tujuan dari penelitian ini adalah untuk mendeskripsikan implementasi kebijakan P3BK di Kecamatan Pondok Melati Kota Bekasi. Ada 4 kelurahan di Kecamatan Pondok Melati yang menjadi wilayah penelitian, yaitu Kelurahan Jatirahayu, Kelurahan Jatiwarna, Kelurahan Jatimelati dan Kelurahan Jatimurni.

Guna mencapai tujuan penelitian, peneliti menggunakan metode penelitian dengan pendekatan kualitatifdeskriptif. Tujuannya adalah untuk menggambarkan prosedur atau langkahlangkah peneliti dalam mengkaji implementasi kebijakan pembangunan Kota Bekasi melalui P3BK. Nantinya akan diperoleh sudut pandang partisipan guna mendapatkan gambaran atau deskripsi secara sistematis, faktual, dan akurat mengenai implementasi kebijakan publik tersebut pada populasi dan tempat penelitian yang ditentukan, yaitu di Kecamatan Pondok Melati Kota Bekasi.

Pengumpulan data dalam penelitian dengan pendekatan kualitatif dilakukan oleh penulis sebagai peneliti, karena peneliti harus terjun sendiri ke lapangan secara aktif, sehingga peneliti merupakan key instrument dalam mengumpulkan data. Teknik pengumpulan data yang digunakan penulis sebagai peneliti meliputi: (a) teknik wawancara terstruktur (structured interview), yaitu peneliti atau pengumpul data telah mengetahui dengan pasti tentang informasi apa yang akan diperoleh dari para informan. Wawancara dilakukan dengan SKPD Kota Bekasi seperti Kepala Bagian Pembangunan, Sekretariat Daerah (Setda) Kota Bekasi, Camat Pondok Melati, Lurah dan Ketua BKM tentang evaluasi implementasi kebijakan P3BK di Kecamatan Pondok Melati, yang dilihat dari 4 variabel yang sangat menentukan keberhasilan implementasi kebijakan publik. Edwards III (1980) menyatakan bahwa ada empat variabel yang menentukan keberhasilan implementasi publik, yaitu: komunikasi, sumber daya, disposisi, dan struktur birokrasi. (b) Teknik dokumentasi, yaitu untuk mendukung hasil pengamatan dan wawancara, maka peneliti akan mengumpulkan data yang kredibel dari dokumen-dokumen rapat dan lain sebagainya.

Penentuan sampel atau informan dalam penelitian ini dilakukan dengan teknik nonprobability sampling yaitu menentukan sampel atau informan secara tidak acak. Penelitian kualitatif tidak melakukan generalisasi sebab masalah yang diteliti hanya berlaku pada lokus yang diteliti. Sehingga informan yang dipilih secara sengaja tanpa acak diharapkan mengetahui apa yang menjadi fokus masalah.

Teknik untuk menganalisis data secara kualitatif dapat dilakukan dalam beberapa metode. Untuk penelitian ini, peneliti menganalisis data dengan Model Miles dan Huberman (Sugiyono, 2016: 246) yang mengungkapkan bahwa aktivitas dalam analisis data kualitatif dilakukan secara interaktif dan berlangsung secara terus menerus sampai tuntas, sehingga datanya sudah jenuh. 


\section{Pengertian Implementasi Kebijakan Publik}

Merille S. Grindle (dalam Tresiana \& Duadji, 2017:46) menyatakan bahwa "implementasi kebijakan merupakan proses umum tindakan administratif yang dapat diteliti pada tingkat program tertentu". Proses implementasi baru akan dimulai apabila tujuan dan sasaran telah ditetapkan, program kegiatan telah tersusun dan dana telah siap disalurkan untuk mencapai sasaran. Sementara Tresiana dan Duadji (2017:48) memahami "implementasi kebijakan sebagai kegiatan mendistribusikan keluaran kebijakan (to deliver policy output) yang dilakukan oleh para pelaksana kepada kelompok sasaran (target group) sebagai upaya mewujudkan tujuan kebijakan". Tujuan kebijakan diharapkan akan muncul manakala policy output dapat diterima dan dimanfaatkan dengan baik oleh kelompok sasaran sehingga dalam jangka panjang hasil kebijakan akan mampu diwujudkan.

Dalam tataran praktis, Mulyadi (2015:12) mengutarakan bahwa implementasi adalah proses pelaksanaan keputusan dasar, yang terdiri atas beberapa tahapan, yakni:

Tahapan pengesahan peraturan perundangan;

1. Pelaksanaan keputusan oleh instansi pelaksana;

2. Kesediaan kelompok sasaran untuk menjalankan keputusan;

3. Dampak nyata keputusan baik yang dikehendaki maupun tidak;

4. Dampak keputusan sebagaimana yang diharapkan instansi pelaksana;

5. Upaya perbaikan atas kebijakan atau peraturan perundangan.

Proses persiapan implementasi setidaknya menyangkut beberapa hal penting, yakni (Saputra, 2018) : (1) Penyiapan sumber daya, unit dan metode; (2) Penerjemahan kebijakan menjadi rencana dan arahan yang dapat diterima dan dijalankan; kemudian (3) Penyediaan layanan, pembayaran dan hal lain secara rutin.

Oleh karena itu, implementasi sebuah kebijakan merupakan tindakan sistematis dari pengorganisasian, penerjemahan dan aplikasi.

Berikut ini merupakan tahapan-tahapan operasional implementasi sebuah kebijakan:
1. Tahapan interpretasi. Tahapan ini merupakan tahapan penjabaran kebijakan yang bersifat abstrak dan sangat umum ke dalam kebijakan atau tindakan yang lebih bersifat manajerial dan operasional. Dalam tahapan ini juga berupa proses komunikasi dan sosialisasi kebijakan tersebut, baik yang berbentuk abstrak maupun operasional kepada para pemangku kepentingan.

2. Tahap pengorganisasian. Beberapa kegiatan yang harus dilakukan pada tahap pengorganisasian, yaitu:

a) Penentuan pelaksana kebijakan (policy implementor) atau aktor implementasi kebijakan, yang setidaknya dapat diidentifikasikan terdiri dari pemerintah (baik pusat maupun daerah), sektor swasta, LSM maupun komponen masyarakat;

b) Penentuan prosedur tetap kebijakan yang berfungsi sebagai pedoman, petunjuk dan referensi bagi pelaksana dan sebagai pencegah terjadinya kesalahpahaman saat para pelaksana tersebut mengalami masalah;

c) Penentuan besaran anggaran biaya dan sumber pendanaan;

d) Penentuan peralatan dan fasilitas yang diperlukan;

e) Penetapan manajemen pelaksana kebijakan diwujudkan dalam penentuan pola kepemimpinan dan koordinasi pelaksanaan; serta

f) Penetapan jadwal pelaksanaan kebijakan

3. Tahapan Implikasi. Tindakan dalam tahap ini adalah perwujudan masing-masing tahapan yang telah dilaksanakan sebelumnya. Faktorfaktor yang dapat mempengaruhi keberhasilan implementasi kebijakan publik adalah: (a) Isi dan konten kebijakan; (b) Pelaksana dan kelompok target; dan (c) Lingkungan.

Menurut Zainal Abidin (Mulyadi, 2015:26) proses implementasi berkaitan dengan faktor utama internal yaitu kebijakan yang akan diimplementasikan, dan faktor utama eksternal adalah kondisi lingkungan dan pihak-pihak terkait. 
Kondisi kebijakan adalah faktor yang paling dominan dalam proses implementasi karena yang diimplementasikan justru kebijakan itu sendiri. Pada tingkat pertama, berhasil tidaknya implementasi suatu kebijakan ditentukan oleh kualitas kebijakan dan ketetapan strategi implementasi.

Implementasi suatu kebijakan pada dasarnya adalah suatu perubahan atau transformasi yang bersifat multiorganisasi, di mana perubahan yang diterapkan melalui strategi implementasi kebijakan ini mengaitkan berbagai lapisan masyarakat. Oleh karena itu, keberhasilan sangat ditentukan oleh strategi kebijakan yang tepat yang mampu mengakomodasi berbagai pandangan dan kepentingan yang berbeda dalam masyarakat.

Chief J.O. Udoji (dalam Agustino, 2016: 129) menuliskan bahwa "The execution of policies is as important if not more important than policy making. Policies will remain dreams or blue print file jackets uses there are implemented", yang diterjemahkan secara bebas bahwa implementasi kebijakan adalah sesuatu yang penting bahkan mungkin jauh lebih penting daripada formulasi kebijakan. Kebijakan hanya akan sekadar berupa impian atau rencana bagus yang tersimpan rapi dalam arsip kalau tidak dilaksanakan.

Keberhasilan kebijakan atau program dikaji berdasarkan perspektif proses implementasi dan perspektif hasil. Pada perspektif proses, program pemerintah dikatakan berhasil jika pelaksanaannya sesuai dengan petunjuk dan ketentuan pelaksanaan yang dibuat oleh pembuat program yang mencakup antara lain cara pelaksanaan, agen pelaksana, kelompok sasaran, dan manfaat program. Sementara itu, dari perspektif hasil, program dapat dinilai berhasil manakala program membawa dampak seperti yang diinginkan. Suatu program bisa saja berhasil dilihat dari sudut proses, akan tetapi bisa saja gagal jika ditinjau dari dampak yang dihasilkannya.

\section{Hasil Penelitian}

Peneliti telah melakukan pengumpulan data sebelumnya melalui wawancara dan beberapa bahan referensi berupa dokumen pertanggungjawaban pelaksanaan P3BK di 4 kelurahan yang ada di Kecamatan Pondok Melati, foto, dan pengamatan langsung di lapangan berupa hasil atau output pelaksanaan P3BK. Data yang didapat tersebut, selanjutnya diuji keabsahannya dengan melakukan triangulasi baik triangulasi sumber maupun triangulasi Teknik.

Triangulasi sumber dilakukan dengan menguji kredibilitas data melalui berbagai sumber yaitu antara pelaksana swakelola P3BK dalam hal ini pengurus BKM Kelurahan, dengan data pada aparatur Kecamatan dan kelurahan selaku penanggung jawab dan pelaksana kegiatan serta Bagian Pembangunan setda Kota Bekasi sebagai Pembina P3BK. Triangulasi teknik dilakukan dengan menguji kredibilitas data pada sumber yang sama dengan teknik yang berbeda, yaitu melalui wawancara dan observasi serta dokumentasi.

Hasilnya bahwa data yang didapat peneliti adalah kredibel atau dapat dipercaya, karena memiliki kesamaan dan konsistensi pada datayang didapatkan. Selanjutnya peneliti melakukan uji keabsahan data yang didapatkan dalam penelitian dengan menggunakan indikator yang sama dan mengacu kepada ketentuan perundang-undangan yang berlaku sebagai pedoman pelaksanaan kegiatan P3BK pada seluruh kelurahan di Kota Bekasi.

Hasilnya, karena data yang dijadikan bahan penelitian jelas, sistematis dan rinci serta mengacu pada ketentuan kebijakan yang ada, sehingga penelitian yang dilakukan pada Kecamatan Pondok Melati dinilai memiliki transferability yaitu dapat diaplikasikan di 11 kecamatan lainnya di Kota Bekasi yang juga melaksanakan P3BK.

Peneliti juga melakukan uji keabsahan data dengan uji dependability dan uji confirmability yang menjadi satu kesatuan dalam prosesnya, yaitu bahwa peneliti benar-benar menyajikan data yang didapat dari hasil dan proses penelitian, baik proses wawancara, observasi lapangan, dokumentasi maupun proses mempelajari referensi sumber data. 
Peneliti melakukan uji keabsahan terhadap data primer dan sekunder yang diperlukan dalam penelitian ini, selanjutnya melakukan analisis data, yang dilakukan dengan Model Miles dan Huberman yaitu dengan melakukan reduksi data, penyajian data dan selanjutnya mengambil kesimpulan dan verifikasi.

Adapun strategi yang dipergunakan peneliti dalam analisis data yang telah didapatkan adalah dengan strategi narrative dan strategi phenomenologis. Strategi narrative dilakukan melalui studi kehidupan informasi dengan cara menanyakan pandangan informan tentang implementasi P3BK dan tingkatan partisipasi masyarakat terkait pelaksanaan program tersebut, yang selanjutnya digabungkan dengan data teks lainnya. Sedangkan strategi phenomenologis dilakukan untuk mendapatkan data dengan mengidentifikasi pengalaman informan maupun penerima manfaat implementasi P3BK sehingga diketahui bagaimana implementasi P3BK maupun tingkatan partisipasi masyarakat terhadap pelaksanaan program tersebut.

Berdasarkan langkah pengumpulan data oleh peneliti dan uji keabsahan data, maka ditemukan berbagai hasil penelitian yang dijadikan bahan analisis guna mendeskripsikan hasil penelitian, sebagai berikut.

\section{Implementasi Kebijakan melalui P3BK}

Sebagaimana tujuan dilakukannya penelitian ini, maka hal pertama yang akan dibahas yaitu evaluasi implementasi kebijakan P3BK di Kecamatan Pondok Melati, yang dilihat dari 4 variabel yang sangat menentukan keberhasilan implementasi kebijakan publik menurut model implementasi yang dikembangkan oleh Edwards III (1980), sebagai berikut:

\section{a. Komunikasi}

Variabel komunikasi yang digunakan untuk melakukan evaluasi implementasi kebijakan dapat dilihat dari 3 (tiga) indikator yaitu transmisi, kejelasan, dan konsistensi.

1) Transmisi

Indikator transmisi dari variabel komunikasi yang digunakanuntukmengevaluasi implementasi kebijakan P3BK yaitu terkait penyaluran komunikasi berupa informasi pelaksanaan P3BK di wilayah kelurahan. Bentuk media penyaluran informasi tersebut terdiri dari forum Musrenbang Kelurahan, pertemuan warga tingkat RW, pertemuan warga tingkat RT, pertemuan kaderkader Posyandu dan PKK atau pertemuan warga lainnya yang bersifat insidentil di tingkat RW maupun tingkat kelurahan. Pertemuan insidentil dimaksud pada umumnya terkait berbagai kegiatan, akan tetapi juga dimanfaatkan untuk menyampaikan informasi terkait pelaksanaan P3BK. Bentuk lainnya yaitu melalui media sosial seperti grup Whatsapp (WA) tingkat Kelurahan yang didalamnya beranggotakan pengurus RW, RT dan lembaga lainnya tingkat kelurahan, facebook, twitter, maupun website Kecamatan.

Forum Musrenbang kelurahan merupakan media penyaluran terpenting dalam implementasi P3BK. Karena media tersebut merupakan wadah perencanaan kegiatan yang akan dilaksanakan melalui P3BK dan bentuk pertanggungjawaban atas pelaksanaan kegiatan P3BK yang telah selesai. Semua kegiatan yang akan dilaksanakan dengan pendanaan P3BK harus tercantum dalam dokumen usulan kegiatan hasil Musrenbang Kelurahan yang merupakan muara atas usulan masyarakat dari tingkat terendah yaitu tingkat RT. Setelah dibahas bersama dengan berbagai pertimbangan dan memperhatikan asas perencanaan, selanjutnya untuk ditetapkan skala prioritas atas kegiatan yang terlebih dahulu akan dilaksanakan melalui P3BK.

Cukup tingginya tingkat kehadiran stakeholder dalam Musrenbang Kelurahan, menandakan cukup tingginya animo dan kepercayaan masyarakat dalam mengkomunikasikan kebutuhan masyarakat khususnya atas pembangunan di wilayah, dan menilai cara ini sebagai saluran komunikasi yang baik dan efektif menyalurkan aspirasi masyarakat tersebut.

Media pertemuan lainnya merupakan wadah menampung dan menyaring aspirasi masyarakat akan kebutuhan pembangunan di wilayah yang nantinya dapat dijadikan bahan perumusan usulan kegiatan P3BK. Pertemuan tersebut juga dijadikan wadah sosialisasi atas kemajuan pelaksanaan 
kegiatan, bentuk pertanggungjawaban informal atas hasil pelaksanaan kegiatan dan wadah evaluasi atas pelaksanaan kegiatan P3BK. Hal di atas sesuai dengan informasi yang didapatkan dari informan baik Kabag Pembangunan, Camat, Lurah, Ketua BKM, dan Ketua LPM yang menginventarisir media tersebut sebagai wadah penyaluran komunikasi dan berjalan cukup efektif.

Penyaluran komunikasi dinilai cukup efektif karena masing-masing pihak yaitu pelaksana program maupun masyarakat penerima hasil program dapat memahami tujuan $\mathrm{P} 3 \mathrm{BK}$ dan memiliki pemahaman yang cukup jelas akan tahapan maupun teknis pelaksanaan P3BK. Hal ini menjadi faktor pendorong keberhasilan implementasi kebijakan P3BK di Kecamatan Pondok Melati.

\section{2) Kejelasan}

Indikatorkejelasandalamvariabelkomunikasi yang perlu dievaluasi terhadap implementasi kebijakan P3BK di Kecamatan Pondok Melati yaitu kejelasan atas kebijakan P3BK oleh para pelaksana kegiatan, baik birokrasi dalam hal ini unsur kecamatan dan kelurahan, maupun unsur pengurus BKM selaku pelaksana swakelola. Hal-hal terkait teknis pelaksanaan kegiatan sebagaimana diatur dalam petunjuk teknis harus jelas diterima dan dipahami oleh pelaksana, agar tujuan P3BK dapat tercapai dengan baik dan optimal. Menurut Kabag Pembangunan Setda, Camat, Lurah dan Ketua BKM penyelenggaraan P3BK di masing-masing kelurahan sudah cukup jelas. Informan menyatakan bahwa informasi yang didapatkan sudah cukup baik dan sebagian besar menyatakan sudah baik dan jelas. Hal tersebut menjadi pendukung keberhasilan pelaksanaan P3BK di Kecamatan Pondok Melati. Hal ini juga sejalan dengan model pendekatan yang diutarakan oleh Van Meter dan Van Horn (1975), bahwa kinerja implementasi kebijakan dapat diukur tingkat keberhasilannya jika dan hanya jika ukuran dan tujuan dari kebijakan memang realistis dengan sosio kultur yang ada di tingkat pelaksana kebijakan. Ukuran dan tujuan kebijakan P3BK sudah sangat jelas dan terukur, serta realistis untuk dilaksanakan oleh pelaksana kebijakan P3BK di Kecamatan Pondok Melati.

\section{3) Konsistensi}

Indikator konsistensi dalam variabel komunikasi yang perlu dievaluasi terhadap implementasi kebijakan P3BK di Kecamatan Pondok Melati dilihat dari konsistensi arahan yang diberikan dalam penyelenggaraan kegiatan P3BK. Dalam hal ini, konsistensi oleh unsur kecamatan dan unsur kelurahan dalam memberikan arahan kepada pengurus BKM sebagai pelaksana/pengelola swakelola sesuai dengan ketentuan yang diatur guna tercapainya tujuan dan target kegiatan P3BK. Berdasarkan informan yaitu para Ketua BKM kelurahan, bahwa baik unsur kecamatan maupun kelurahan sudah secara konsisten dalam memberikan arahan terkait penyelenggaraan P3BK. Hanya ada 1 Ketua BKM yaitu Ketua BKM Kelurahan Jatimelati yang menyatakan belum maksimal.

Ketua BKM Kelurahan Jatirahayu mengutarakan; "Kalau terkait konsistensi memberikan arahan saya lihat belum maksimal ya.. Arahannya kadang suka kurang jelas atau berbeda antara Seksi Pemberdayaan Masyarakat Kecamatan dengan bagian keuangannya, jadi kadang bikin bingung." Dari pernyataan tersebut maka dapat diartikan bahwa masih diperlukan peningkatan pemahaman masingmasing pengelola kegiatan $\mathrm{P} 3 \mathrm{BK}$, sehingga dalam memberikan arahan pun dapat konsisten. Konsistensi dalam komunikasi akan dapat terwujud dengan kemampuan berkoordinasi yang baik pula antara masing-masing pihak yang terlibat dalam proses implementasi kebijakan, guna menghindari kesalahan yang akan terjadi, sebagaimana diutarakan oleh Van Meter \& Van Horn (1975). Hal tersebut yang diterapkan oleh unsur kecamatan dan kelurahan dalam menjaga konsistensi komunikasi dengan pengurus BKM selaku pelaksana swakelola. Koordinasi yang senantiasa dilakukan selama proses pelaksanaan kegiatan menjadi hal utama perwujudan konsistensi.

Berdasarkan 3 (tiga) indikator variabel komunikasi di atas, maka dapat disimpulkan 
bahwa transmisi, kejelasan dan konsistensi komunikasi dalam implementasi kebijakan P3BK di Kecamatan Pondok Melati sudah baik, dengan tetap memperhatikan upaya pembekalan guna mendapatkan persamaan pemahaman kebijakan oleh pelaksana kebijakan sebagai upaya menciptakan konsistensi penyampaian informasi. Kondisi tersebut menjadi faktor pendorong keberhasilan implementasi kebijakan P3BK di Kecamatan Pondok Melati.

\section{b. Sumber Daya}

Variabel sumber daya yang digunakan untuk melakukan evaluasi implementasi kebijakan dapat dilihat dari 4 (empat) indikator yaitu staf, informasi, wewenang dan fasilitas.

\section{1) Staf}

Indikator staf dalam variabel sumber daya yang perlu dievaluasi terhadap implementasi kebijakan P3BK di Kecamatan Pondok Melati dilihat dari sumber daya manusia (SDM) yang merupakan sumber daya utama dalam implementasi kebijakan. SDM dengan jumlah yang cukup, dan memiliki keahlian serta kemampuan yang diperlukan merupakan kondisi SDM yang dibutuhkan guna keberhasilan implementasi P3BK di Kecamatan Pondok Melati.

Berdasarkan data yang ada, secara jumlah sumber daya berupa SDM sudah mencukupi, baik dari unsur kecamatan, unsur kelurahan maupun pengurus BKM kelurahan. Informan Camat, Lurah, Ketua BKM dan Ketua LPM menyatakan bahwa dilihat dari kapasitas dan kapabilitas pelaksana kegiatan P3BK sudah cukup memadai, baik dalam memahami kebijakan maupun dalam hal mengimplementasikan ketentuan tersebut.

Terdapat satu pernyataan Lurah Jatirahayu yang mengungkapkan; "Kalau SDM di Kelurahan yang terlibat pelaksanaan P3BK menurut saya belum optimal. Karena tidak semua menguasai teknis P3BK. Bagaimana teknis pelaksanaan kegiatan pembangunan yang memakai dana P3BK. Mereka belum memiliki kemampuan yang sama."

Berangkat dari pernyataan tersebut, maka meskipun secara umum SDM pelaksana P3BK dinilai cukup memadai, harus tetap dilakukan penguatan maupun menjaga kualitas kemampuan pelaksana, mengingat tingkat kemampuan yang berbeda-beda dan berkelanjutannya program tersebut.

Pentingnya SDM pelaksana program dalam keberhasilan implementasi P3BK di Kecamatan Pondok Melati, sejalan dengan model pendekatan yang diutarakan Marille S. Grindle yaitu bahwa salah satu hal yang menentukan keberhasilan suatu implementasi kebijakan publik adalah pelaksana program yang kompeten dan kapabel.

Oleh karena itu, pemeliharaan dan peningkatan kualitas SDM sebagai implementor kebijakan P3BK harus terus dilakukan, mengingat adanya kemungkinan pergantian personil akibat mutasi dan rotasi pegawai serta adanya pembaharuan terhadap ketentuan teknis P3BK.

2) Informasi

Indikator informasi dalam variabel sumber daya yang perlu dievaluasi terhadap implementasi kebijakan P3BK di Kecamatan Pondok Melati yaitu terkait sejauh mana pelaksana program mengetahui ketentuan yang mengatur penyelenggaraan P3BK dan tingkat kepatuhan pelaksana terhadap ketentuan tersebut dalam pelaksanaan P3BK.

Informan baik Kabag Pembangunan, Camat, Lurah, Ketua BKM dan Ketua LPM menyatakan bahwa pelaksana P3BK di Kecamatan Pondok Melati telah mengetahui dan cukup memahami hal-hal terkait penyelenggaraan $\mathrm{P} 3 \mathrm{BK}$ dari mulai proses perencanaan, pelaksanaan pekerjaan, pengawasan dan evaluasi. Dimana hal tersebut telah diatur secara rinci dalam ketentuan petunjuk teknis pelaksanaan P3BK, yang secara konsisten dijadikan pedoman penyelenggaraan. Pelaksana program juga dinilai telah memiliki kepatuhan terhadap pedoman yang ada. Hal ini terbukti dengan lengkapnya persyaratan administrasi dan teknis yang dibutuhkan dalam proses pencairan dana P3BK maupun dalam proses 
pertanggungjawaban yang telah mendapat hasil pemeriksaan yang baik dari Auditor Pemeriksa Intern Pemerintah (APIP).

Akan tetapi, dipandang perlu terus melakukan peningkatan kepatuhan dari pelaksana program terkait kepatuhan waktu pelaksanaan. Karena masih terjadi keterlambatan pelaksanaan program jika dibandingkan dengan rencana waktu pelaksanaan. Hal ini disebabkan adanya kebutuhan waktu yang berbedabeda di masing-masing wilayah untuk mengkomunikasikan, meyakinkan, dan mendapatkan kesepakatan dari masyarakat penerima manfaat, dalam hal bentuk partisipasi masyarakat.

Hal ini sebagaimana yang diutarakan oleh Camat Pondok Melati bahwa: "Secara aturan BKM sudah melaksanakan kegiatan swakelola P3BK dengan baik dan tertib. Akan tetapi waktu pelaksanaan sering molor sehingga mengakibatkan proses pencairan kegiatan pun menjadi semakin lambat. Karena itu, harus sering-sering diingatkan dan dipantau supaya kegiatannya bisa jalan lebih cepat sesuai rencana".

Oleh karena itu, diperlukan upaya optimalisasi sumber daya khususnya dari segi kepatuhan pemanfaatan waktu oleh pelaksana P3BK di Kecamatan Pondok Melati, agar implementasi kebijakan P3BK berhasil baik. Hal ini juga seturut dengan yang diutarakan Marille S. Grindle bahwa kepatuhan dan respon pelaksana menanggapi suatu kebijakan merupakan hal penting dalam proses implementasi kebijakan. Dan faktor sumber daya berupa sumber daya waktu menjadi faktor keberhasilan implementasi kebijakan sebagaimana diungkap oleh Van Metter dan Van Horn (1975).

3) Wewenang

Indikator wewenang dalam variabel sumber daya yang perlu dievaluasi terhadap implementasi kebijakan P3BK di Kecamatan Pondok Melati yaitu terkait efektivitas kewenangan sebagai otoritas dan legitimasi bagi para pelaksana dalam melaksanakan kebijakan. Wewenang dipandang sebagai sumber daya yang harus dievaluasi efektivitasnya dalam menilai keberhasilan implementasi kebijakan. Karena secara formal, penggunaan wewenang yang efektif sangat diperlukan agar setiap tahapan dan ketentuan yang telah diatur dalam implementasi kebijakan dapat berjalan sesuai dan efektif.

Informan baik Kabag Pembangunan Setda, Camat, Lurah, Ketua BKM dan Ketua LPM menyatakan bahwa penggunaan wewenang oleh masing-masing pelaksana kebijakan sudah sesuai dengan ketentuan yang mengatur kewenangan tersebut, dan sudah berjalan cukup efektif. Hal tersebut terlihat dari tahapan berikut:

Pertama, Seleksi Program Kegiatan. Pada tahapan seleksi program kegiatan, efektivitas kewenangan camat sangat dibutuhkan. Berdasarkan informasi dan data yang ada, Camat Pondok Melati sudah melaksanakan kewenangannya dengan efektif, meliputi penyusunan daftar kebutuhan dan kegiatan prioritas berdasarkan dokumen perencanaan, melakukan verifikasi tingkat kecamatan dengan melibatkan unsur kecamatan, unsur kelurahan dan unsur UPTD di lingkup Kecamatan Pondok Melati terhadap usulan/proposal kegiatan yang diajukan BKM, serta dalam menetapkan BKM kelurahan sebagai pelaksana swakelola di masing-masing kelurahan pada Kecamatan Pondok Melati.

Kedua, Perencanaan Kegiatan Swakelola. Pada tahap perencanaan kegiatan swakelola, penggunaan wewenang BKM yang memegang peranan penting. Karena BKM memiliki wewenang untuk membentuk Tim Swakelola yang melaksanakan kegiatan yang sudah ditetapkan akan didanai melalui P3BK. Pembentukan Tim Swakelola meliputi Tim Perencana, Tim Pelaksana dan Tim Pengawas.

Hasil penelitian mendapati bahwa BKM telah mempergunakan kewenangannya dengan efektif dan sesuai ketentuan. Dalam 
mempergunakan kewenangan inipun masing-masing pengurus BKM Kelurahan melibatkan peran serta pengurus RT/RW setempat atau tokoh masyarakat lainnya.

Ketiga, Pelaksanaan Kegiatan Swakelola. Sesuai kewenangan bahwa pelaksanaan kegiatan swakelola adalah oleh Tim Pelaksana Swakelola yang diangkat oleh Koordinator BKM. Tim Pelaksana Swakelola bertugas melaksanakan pekerjaan yang telah disusun perencanaannya dan mendapat dukungan dari masyarakat. Tim ini juga melakukan pembayaran atas belanja yang dikeluarkan guna realisasi pekerjaan, membuat laporan kemajuan pekerjaan dan dokumentasi. Selanjutnya menyerahkan hasil pekerjaan kepada Camat Pondok Melati selaku Pengguna Anggaran melalui Berita Acara Serah Terima Hasil Pekerjaan.

Kewenangan yang diberikan dan dijalankan oleh masing-masing pelaksana kebijakan P3BK di Kecamatan Pondok Melati, dinilai sudah efektif. Masing-masing unsur menggunakan kewenangannya dengan baik, sehingga proses penyelesaian pekerjaan P3BK dapat berjalan sesuai target yang telah ditentukan dan sesuai rencana, walaupun dari segi waktu masih terdapat beberapa keterlambatan pelaksanaan.

4) Fasilitas

Indikator fasilitas dalam variabel sumber daya yang perlu dievaluasi terhadap implementasi kebijakan P3BK di Kecamatan Pondok Melati yaitu fasilitas pendukung berupa sarana dan prasarana. Fasilitas pendukung yang diperlukan dalam implementasi P3BK secara umum terkait dengan proses administrasi pelaksanaan kegiatan, meliputi ruang kerja pengurus BKM dan Tim Pelaksana Swakelola, perlengkapan dan peralatan kantor.

Berdasarkan kondisi yang ada pada masing-masing kelurahan di Kecamatan Pondok Melati, belum ada ruang khusus pada kantor kelurahan yang dapat dipergunakan pelaksana swakelola dalam melakukan aktivitas perkantoran khususnya dalam rangka mempersiapkan kelengkapan administrasi, baik administrasi perencanaan, pelaksanaan maupun pelaporan. Demikian halnya sarana yang ada, dinilai masih belum memadainya peralatan kantor yang dibutuhkan guna menunjang pelaksanaan tugas pelaksana swakelola. Kondisi tersebut didasarkan pada ketentuan bahwa dana kegiatan P3BK tidak dapat dialokasikan untuk belanja modal berupa peralatan kantor. Hal ini menjadi salah satu faktor penghambat efektivitas pelaksanaan tugas pelaksana swakelola dalam menyelesaikan pekerjaannya. Hal tersebut juga diakui oleh semua informan yaitu Lurah dan para Ketua BKM Kelurahan.

\section{c. Disposisi/Sikap Pelaksana}

Variabel ketiga yang mempengaruhi keberhasilan implementasi kebijakan yaitu disposisi atau sikap pelaksana kebijakan, yang dapat dilihat dari 3 (tiga) indikator yaitu :

1) Efek Disposisi.

Indikator efek disposisi dalam variabel disposisi atau sikap pelaksana kebijakan yang perlu dievaluasi terhadap implementasi kebijakan P3BK di Kecamatan Pondok Melati yaitu mereka yang memiliki dedikasi dalam melihat kepentingan warga.

Seperti ketentuan pembentukan BKM Kelurahan, baik pimpinan dan anggotanya dipilih dari masyarakat wilayah kelurahan dimaksud, dengan berbagai kriteria yang baik yang diharapkan dapat mendorong masyarakat kelurahan lebih aktif dalam meningkatkan keswadayaan masyarakat dalam pembangunan khususnya pada masing-masing kelurahan.

Adapun pelaksana swakelola P3BK bukan hanya terdiri dari pengurus BKM kelurahan, akan tetapi juga melibatkan unsur pengurus RT, RW ataupun tokoh masyarakat lainnya di lokasi pekerjaan P3BK. Oleh karena itu, berdasarkan informasi dari Camat, Lurah, dan Ketua LPM Kelurahan, dan data pelaksanaan pekerjaan, personil pelaksana swakelola merupakan orang-orang yang 
memiliki kapasitas dan kapabilitas cukup memadai untuk melaksanakan kegiatan dimaksud. Selain tingkat pendidikan yang baik, mereka umumnya juga merupakan orang-orang yang secara aktif terlibat dalam kegiatan kemasyarakatan dan memiliki kesamaan tujuan yaitu berperan aktif dalam pembangunan masyarakat khususnya di lingkungan kelurahan.

Personil dari unsur kecamatan dan kelurahan sebagai pelaksana kebijakan, berdasarkan informasi dari Kepala BKM kelurahan, selain juga memiliki kompetensi yang sesuai dengan kewenangannya, mereka juga memiliki dedikasi untuk menjalankan kebijakan P3BK dengan sebaik-baiknya untuk pembangunan masyarakat. Hal ini juga sejalan dengan tanggung jawab dan janji mereka sebagai aparatur sipil negara, yaitu mengabdi kepada negara dan masyarakat. Baik pelaksana swakelola dan unsur kecamatan serta kelurahan, bersamasama bekerja mewujudkan kemajuan dan keswadayaan masyarakat melalui P3BK, salah satunya dengan sikap terbuka, mampu berkomunikasi dengan baik dan menyerap aspirasi serta kebutuhan prioritas di masyarakat khususnya terkait pembangunan. Indikator keberhasilan ini juga sejalan dengan pendapat Van Metter dan Van Horn (1975) yaitu bahwa sikap penerimaan atau penolakan dari agen pelaksana kebijakan akan sangat banyak mempengaruhi keberhasilan atau tidaknya kinerja implementasi kebijakan publik.

2) Pengaturan Birokrasi.

Indikator birokrasi dalam variabel disposisi atau sikap pelaksana kebijakan yang perlu dievaluasi terhadap implementasi kebijakan P3BK di Kecamatan Pondok Melati yaitu terkait pengaturan birokrasi merujuk pada penunjukkan dan pengangkatan staf dalam birokrasi yang sesuai kemampuan, kapabilitas dan kompetensinya.

Indikator ini sejalan dengan indikator staf pada variabel sumber daya, yang harus dievaluasi terkait implementasi kebijakan.
Sesuai informasi yang didapat dan standar kompetensi yang dimiliki oleh birokrasi yang menjalankan kebijakan P3BK, dalam hal ini unsur kecamatan dan unsur kelurahan, telah memiliki kapabilitas yang baik dan kompetensi yang memadai. Karena masing-masing aparatur yang diberikan tugas dan tanggung jawab telah memiliki standar kompetensi yang sesuai dan juga telah menjalankan apa yang menjadi tugas dan tanggung jawabnya dengan baik guna keberhasilan tujuan P3BK.

Akan tetapi, dengan adanya potensi terjadinya mutasi tugas terhadap aparatur birokrasi dimaksud, maka perlu terus melakukan upaya pembinaan terhadap aparatur yang ada, agar tetap memiliki kapasitas yang mumpuni dalam keberhasilan implementasi kebijakan P3BK. Hal inilah yang dilakukan oleh Camat Pondok Melati selaku penanggung jawab P3BK di kecamatan. Camat Pondok Melati melalui berbagai kegiatan, membina, mengkomunikasikan dan melakukan supervisi terhadap aparatur pelaksana program, guna memastikan program tersebut berjalan sesuai ketentuan. Pembinaan dilakukan melalui bimbingan teknis dan pendampingan terkait proses perencanaan, pelaksanaan dan pertanggungjawaban secara teknis dan administrasi kepada aparatur kecamatan, kelurahan maupun BKM selaku pelaksana swakelola. Sementara, supervisi dilakukan melakukan pemeriksaan dokumen perencanaan, pelaksanaan, pertanggungjawaban maupun pengecekan langsung ke lokasi pekerjaan.

3) Insentif.

Indikator insentif dalam variabel disposisi atau sikap pelaksana kebijakan yang perlu dievaluasi terhadap implementasi kebijakan P3BK di Kecamatan Pondok Melati adalah yang terkait upaya pemberian insentif guna mendorong kinerja pelaksana kebijakan.

Insentifyangdiberikandalamimplementasi P3BK adalah insentif berupa dana Biaya Operasional (BOP) yang dapat dipergunakan 
pelaksana kebijakan berdasarkan dokumen perencanaan anggaran. BOP diberikan untuk memfasilitasi dan memberi dorongan kepada pelaksana kebijakan agar pelaksana kebijakan bisa mengerahkan usahanya serta mengoptimalkan usaha tersebut guna mencapai tujuan P3BK.

Fasilitasi melalui dana insentif yaitu untuk memfasilitasi pelaksana kebijakan P3BK khususnya pelaksana swakelola dalam rangka perencanaan, pelaksanaan hingga pertanggungjawaban pelaksanaan kegiatan swakelola. Menurut informasi dari para Ketua BKM Kelurahan, insentif memang telah diterima oleh pelaksana swakelola. Dalam ketentuan standar biaya masukan pemerintah Kota Bekasi, pemberian honorarium atau insentif kegiatan adalah antara Rp200.000 sampai dengan Rp1.800.000 per orang/bulan atau per orang/kegiatan. Pada realisasinya, insentif yang diberikan untuk pelaksana swakelola adalah antara Rp500.000 sampai dengan Rp1.000.000 per orang selama 3 bulan. Nilai tersebut dinilai belum memadai apabila dibandingkan dengan pekerjaan yang dilakukan sepanjang tahun yang kapasitasnya cukup banyak. Akan tetapi kondisi tersebut, berdasarkan informasi dari Camat, Lurah dan para Ketua LPM Kelurahan tidak menyebabkan kinerja pelaksana swakelola menurun. Secara umum para pelaksana swakelola adalah orang-orang yang memiliki dedikasi tinggi terhadap kepentingan masyarakat, dan hal tersebut dibuktikan dengan tetap menunjukkan kinerja yang terbaik guna pencapaian tujuan P3BK.

\section{d. Struktur Organisasi/Birokrasi}

Variabel keempat yang mempengaruhi keberhasilan implementasi kebijakan yaitu struktur organisasi/birokrasi, yang dapat dilihat dari 2 (dua) indikator yaitu :

1) Standar Operasional Prosedur (SOP) Indikator SOP dalam variabel struktur organisasi/birokrasi yang perlu dievaluasi terhadap implementasi kebijakan P3BK di Kecamatan Pondok Melati yaitu terkait prosedur atau aktivitas terencana rutin yang memungkinkan para pelaksana P3BK untuk melaksanakan kegiatannya sesuai dengan standar yang telah ditetapkan. Implementasi kebijakan pembangunan melalui P3BK telah dipersiapkan dengan SOP yang jelas dalam rangka mengatur standar pelaksanaan kegiatan swakelola yang didanai APBD Kota Bekasi berjalan lancar, efektif, efisien dan sesuai ketentuan perundang-undangan. Hal tersebut sebagaimana diatur dalam Peraturan Walikota Bekasi Nomor 106 Tahun 2016 tentang Petunjuk Teknis Penyelenggaraan Program Pembangunan Partisipatif Berbasis Komunitas di Kota Bekasi sebagaimana telah diubah dengan Peraturan Walikota Bekasi Nomor 18 Tahun 2017.

SOP pelaksanaan kegiatan $\mathrm{P} 3 \mathrm{BK}$ juga terkait dengan beberapa SOP lainnya secara khusus yang berkenaan dengan proses pencairan dana, pembayaran dan pertanggungjawaban anggaran. Berdasarkan informasi dari Kepala Bagian (Kabag) Pembangunan Setda, Camat dan Lurah bahwa implementasi P3BK senantiasa mengacu kepada SOP yang telah ditetapkan. Hal tersebut juga dilakukan oleh BKM selaku pelaksana swakelola.

Akan tetapi, terkait kelengkapan administrasi masih diperlukan berbagai upaya peningkatan kualitas. Belum optimalnya pengelolaan administrasi perencanaan, pelaksanaan dan pertanggungjawaban P3BK yang dilakukan BKM menjadi salah satu kendala pelaksanaan kegiatan swakelola berjalan tidak tepat waktu. Hal ini disebabkan karena pengurus BKM bukan berasal dari Aparatur Sipil Negara (ASN), sehingga belum memiliki pemahaman yang cukup terkait dokumen administrasi dimaksud. Sehubungan kondisi tersebut, Camat selaku penanggung jawab program beserta jajarannya, terus melakukan upaya pembinaan dan pendampingan, serta supervisi agar proses administrasi yang dilakukan berjalan baik dan sesuai ketentuan SOP yang ada.

Pembinaan, pendampingan, dan supervisi 
pelaksanaan kegiatan P3BK menjadi tanggung jawab pengelola kegiatan belanja langsung P3BK di Kecamatan Pondok Melati. Hal tersebut telah berjalan baik, sehingga pelaksanaan P3BK di Kecamatan Pondok Melati secara teknis dan administrasi telah berjalan sesuai ketentuan dan target yang ditentukan.

\section{2) Fragmentasi}

Indikator fragmentasi dalam variabel struktur organisasi/birokrasi yang perlu dievaluasi terhadap implementasi kebijakan P3BK di Kecamatan Pondok Melati yaitu terkait fragmentasi birokrasi yaitu menyebar tanggung jawab pelbagai kegiatan pada beberapa unit kerja. Fragmentasi birokrasi diharapkan akan mendorong efektifitas implementasi kebijakan karena dilaksanakan oleh organisasi yang kompeten dan kapabel.

Melihat dan mempelajari implementasi kebijakan P3BK di Kecamatan Pondok Melati, maka dapat digambarkan bahwa fragmentasi birokrasi telah berjalan efektif. Tanggung jawab telah dibagi berdasarkan posisi birokrasi secara berjenjang dan terstruktur. Dari mulai tingkat kelurahan, kecamatan hingga tingkat Kota Bekasi melalui Bagian Pembangunan Setda Kota Bekasi.

Masing-masing unsur memiliki tanggung jawab dan mengambil peranan dalam tahapantahapan penyelenggaraan P3BK, sebagaimana telah diatur dalam petunjuk teknis dan SOP. Adanya fragmentasi birokrasi yang jelas dan konsistensi menjalankan tugas dan tanggung jawab tersebut, mendorong keberhasilan P3BK di Kecamatan Pondok Melati.

\section{Penutup}

Berdasarkan hasil penelitian yang telah dilakukan pada objek penelitian dan strategi analisa data yang didapatkan pada proses penelitian, dapat diambil simpulan sebagai berikut:

1. Implementasi kebijakan P3BK di Kecamatan Pondok Melati Kota Bekasi berjalan baik dan sesuai dengan sasaran dan tujuan program. Yang menjadi faktor pendorong keberhasilan implementasi kebijakan P3BK di Kecamatan Pondok Melati Kota Bekasi adalah (a) faktor komunikasi yang meliputi penyaluran komunikasi yang cukup efektif, kejelasan yang cukup baik atas kebijakan P3BK oleh para pelaksana kegiatan, serta konsistensi dalam memberikan arahan yang cukup baik; (b) faktor sumber daya yang meliputi SDM pelaksana program yang dinilai cukup kompeten dan kapabel meski berlatar belakang pendidikan maupun tingkat pendidikan yang berbeda-beda, pelaksana P3BK yang telah mengetahui dan cukup memahami penyelenggaraan P3BK, tingkat kepatuhan yang cukup terhadap pedoman pelaksanaan yang ada, serta efektifnya penggunaan kewenangan; (c) faktor disposisi/sikap pelaksana P3BK yang meliputi kapasitas dan kapabilitas pelaksana P3BK yang cukup memadai, dedikasi yang tinggi untuk menjalankan kebijakan P3BK, kapasitas dan kompetensi aparatur kecamatan dan kelurahan yang memadai, serta adanya insentif bagi pelaksana P3BK; dan (d) faktor struktur organisasi/birokrasi yang meliputi telah tersedianya SOP pelaksanaan P3BK dan masing-masing pelaksana program telah memahami dan melaksanakan SOP tersebut, serta fragmentasi birokrasi yang telah berjalan efektif. Adapun yang masih menjadi faktor penghambat optimalisasi implementasi kebijakan P3BK adalah masih ditemukan terjadinya beberapa perbedaan pemahaman teknis oleh pelaksana kegiatan yang mengakibatkan kurang konsistennya informasi yang diterima pelaksana swakelola, masih adanya kekurangan fasilitas penunjang implementasi P3BK, adanya potensi perpindahan tugas aparatur kecamatan dan kelurahan pelaksana P3BK, belum mencukupinya insentif yang dibutuhkan guna menunjang kinerja pelaksana P3BK, serta adanya pemahaman yang kurang memadai terkait administrasi perencanaan, pelaksanaan dan pertanggungjawaban P3BK.

2. Tingkatan partisipasi masyarakat Kecamatan 
Pondok Melati dalam implementasi P3BK secara umum telah melalui semua tingkatan partisipasi yaitu memberikan informasi, partisipasi dalam konsultasi, tingkat partisipasi substansial yaitu pengambilan keputusan bersama, bertindak bersama dan akhirnya partisipasi memberikan dukungan.

Berdasarkan simpulan tersebut, maka peneliti dapat merumuskan beberapa saran yang dapat dijadikan masukan dan bahan perbaikan guna optimalisasi implementasi P3BK di beberapa kecamatan di Kota Bekasi, sebagai berikut:

1. Guna mendapatkan persamaan pemahaman kebijakan oleh pelaksana P3BK sebagai upaya menciptakan konsistensi penyampaian informasi maupun memelihara kapasitas dan kapabilitas pelaksana P3BK, maka setiap Camat harus tetap melakukan upaya pembinaan melalui pembekalan, pendampingan dan supervisi secara regular dan berjenjang ke tingkat kelurahan, terkait pelaksanaan $\mathrm{P} 3 \mathrm{BK}$ dimulai dari proses perencanaan, pelaksanaan hingga pertanggungjawaban $\mathrm{P} 3 \mathrm{BK}$ secara teknis maupun administrasi, sesuai SOP dan ketentuan yang telah ditetapkan.

2. Sebagai penanggungjawab program, Camat dapat memberikan masukan dan dorongan untuk dilakukan peningkatan sarana prasarana penunjang pelaksanaan P3BK, maupun insentif yang diberikan bagi pelaksana $\mathrm{P} 3 \mathrm{BK}$ dalam rangka meningkatkan kinerja pelaksana $\mathrm{P} 3 \mathrm{BK}$.

3. Camat dan jajarannya, secara terus-menerus perlu memanfaatkan berbagai media komunikasi untuk menekankan dan memberi pemahaman pentingnya peran aktif berupa partisipasi substansial dari masyarakat, dalam rangka mengoptimalkan pembangunan secara khusus pembangunan masyarakat yang berbasis komunitas, sehingga kebijakan pembangunan Pemerintah Kota Bekasi khususnya melalui P3BK dapat diimplementasikan dengan efektif efisien sebagai langkah pencapaian tujuan yang telah ditetapkannya dalam kebijakan tersebut.

\section{DAFTAR PUSTAKA}

Agustino, L. (2016). Dasar-dasar Kebijakan Publik. Bandung: Alfabeta.

Anggara, S. (2014). Kebijakan Publik. Bandung: Pustaka Setia.

Arikunto, S. (2006). Prosedur Penelitian Suatu Pendekatan Praktik. Jakarta: PT Rineka Cipta.

Edwards III, George C. (1980). Implementing Public Policy. Washington, D.C.: Congressional Quarterly Press.

Hamdi, M. (2013). Kebijakan Publik Proses, Analisis dan Partisipasi. Jakarta: Ghalia Indonesia.

Harli, M. (2013). Implementasi Program Gerakan Pembangunan Rakyat (Gapura) Sa-Ijaan di Desa Sungai Kupang Jaya Kecamatan Kelumpang Selatan Kabupaten Kotabaru Kalimantan Selatan. Jurnal Ilmu Politik dan Pemerintahan Lokal, II (2) Juli-Desember 2013.

Keban, Y. T. (2008). Enam Dimensi Strategis Administrasi Publik Konsep, Teori dan Isu. Yogyakarta: Gava Media.

Kusumanegara, S. (2009). Model dan Aktor Dalam Proses Kebijakan Publik. Purwokerto: Gava Media.

Laily, E. I. N. (2015). Partisipasi Masyarakat dalam Perencanaan Pembangunan Partisipatif. Jurnal Kebijakan dan Manajemen Publik, 3(2) MeiAgustus.

Mardikanto, T. \& Soebianto, P. (2012). Pemberdayaan Masyarakat dalam Perspektif Kebijakan Publik. Bandung: Alfabeta.

Moleong, L. J. (2017). Metodologi Penelitian Kualitatif. Bandung: PT Remaja Rosdakarya.

Mulyadi, D. (2015). Studi Kebijakan Publik dan Pelayanan Publik, Konsep dan Aplikasi Proses Kebijakan Publik Berbasis Analisis Bukti untuk Pelayanan Publik. Bandung: Alfabeta.

Mulyadi, M. (2012). Peningkatan Kualitas Sumber Daya Manusia untuk Pencapaian Pembangunan Milenium (MDGs). Info Singkat. Jakarta: Puslit DPR RI.

Mulyadi, M. (2014). Kemiskinan Identifikasi Penyebab dan Penanggulangannya. Jakarta: Pusat Pengkajian, Pengolahan Data dan Informasi (P3DI) Sekretariat Jenderal DPR RI bersama Publica Press.

Mulyadi, M. (2016). Metode Penelitian Praktis Kuantitatif dan Kualitatif. Jakarta: Publica Press. 
Peraturan Wali Kota Bekasi Nomor 106 Tahun 2016 Tentang Petunjuk Teknis Penyelenggaraan Program Pembangunan Partisipatif Berbasis Komunitas Di Kota Bekasi (2016).

Saputra, Z.S.L.D.A. (2018). Kebijakan Pemerintah Kabupaten Malang Dalam Pengembangan Sektor Pariwisata Berbasis Potensi Lokal. (Studi pada Objek Wisata Coban Sewu, Coban Gintung, Coban Telaga Warna dan Coban Ciblungan Desa Sidorenggo Kecamatan Ampelgading Kabupaten Malang) (skripsi). University of Muhammadiyah Malang, Malang

Siagian, S. P. (2000). Administrasi Pembangunan Konsep, Dimensi dan Strateginya. Jakarta: PT Bumi Aksara.

Soleh, C. (2014). Dialektika Pembangunan dengan Pemberdayaan. Jatinangor: Fokusmedia.

Sugiyono. (2006). Metode Penelitian Kuantitatif, Kualitatif, dan R\&D. Bandung: Alfabeta.

Theresia, A., et al., (2014). Pembangunan Berbasis Masyarakat Acuan bagi Praktisi, Akademisi, dan Pemerhati Pengembangan Masyarakat. Surakarta: Alfabeta.

Tiza, A. L., et al., (2014). Implementasi Program Pembangunan Desa Mandiri Anggaran untuk Rakyat Menuju Sejahtera (Anggur Merah) (Studi di Badan Perencanaan Pembangunan Daerah Kabupaten Timor Tengah Utara). Wacana, 17(1).

Tjiptoherijanto, P dan Manurung, M. (2017). Paradigma Administrasi Publik dan Perkembangannya. Jakarta: PT Rineka Cipta.

Tresiana, N. \& Djuaji, N. (2017). Kebijakan Publik Teori dan Praktek Model-model Pengelolaan Pembangunan Daerah. Bandar Lampung: Suluh Media.

Van Meter, D. S., \& Van Horn, C. (1975). The Policy Implementation Process: A Conceptual Framework. Administration \& Society, 6(4), 445-488. https:// doi.org/10.1177/009539977500600404

Wahab, S. A. (2012). Analisis Kebijakan dari Formulasi ke Penyusunan Model-Model Implementasi Kebijakan Publik. Malang: Bumi Aksara.

Wahyudi, J. (2016). Implementasi Pembangunan Berbasis Rukun Tetangga (PBRT): Pengalaman Tata Kelola Pemerintahan di Kabupaten Sumbawa Barat. Jurnal Ilmu Pemerintahan, 9(1) Januari. 